\title{
Replacement of starch from corn with nonforage fiber from distillers grains and soyhulls in diets of lactating dairy cows ${ }^{1}$
}

\author{
S. D. Ranathunga, K. F. Kalscheur, ${ }^{2}$ A. R. Hippen, and D. J. Schingoethe \\ Dairy Science Department, South Dakota State University, Brookings 57007
}

\section{ABSTRACT}

Forty Holstein cows were used in a completely randomized design with a 2-wk covariate period followed by a 6 -wk experimental period to evaluate incremental substitution of nonforage fiber provided by dried distillers grains with solubles (DDGS) and soyhulls (SH) for starch provided by corn in the diet. Diets provided decreasing concentrations of starch: $29 \%$ starch with $0 \%$ DDGS; $26 \%$ starch with 7\% DDGS; $23 \%$ starch with $14 \%$ DDGS; and 20\% starch with 21\% DDGS. Diets contained $27 \%$ corn silage, $22 \%$ alfalfa hay, and $51 \%$ concentrate mix and were formulated to be $17 \%$ crude protein, $4.7 \%$ fat, and $23 \%$ neutral detergent fiber from forage. Total neutral detergent fiber increased as DDGS and SH were included in the diet. Soyhulls were included in a linear fashion along with DDGS to replace soybean meal and expeller soybean meal, thereby maintaining a similar crude protein content across diets. Dry matter intake decreased linearly; consequently, feed efficiency tended to increase linearly as starch was replaced by nonforage fiber. There was no effect of diet on milk production or milk fat and protein percentage or yield. Milk fatty acid profiles were similar across diets. Other response variables, including $4 \%$ fat-corrected milk, total solids, and milk urea nitrogen, were unaffected by dietary treatments. Ruminal volatile fatty acid concentration did not differ between diets. Concentrations of blood glucose and $\beta$-hydroxybutyrate were similar across diets. Results from this research suggest that nonforage fiber from DDGS can partially substitute for starch from corn in dairy cow diets without affecting milk production and milk composition. Economic analysis of the diets showed that feeding DDGS and SH in substitution of corn was cost-effective. Results from this experiment indicate that DDGS and SH can replace corn as an energy source to decrease feed costs.

Key words: dried distillers grain with solubles, nonforage fiber, soyhull, starch

\footnotetext{
Received April 28, 2009.

Accepted November 16, 2009.

${ }^{1}$ Publication number 3633 of the South Dakota Agricultural Experiment Station Journal Series.

${ }^{2}$ Corresponding author: kenneth.kalscheur@sdstate.edu
}

\section{INTRODUCTION}

Starch is a major source of energy in diets fed to high-producing dairy cows and accounts for 50 to $100 \%$ of the NSC in most feedstuffs (NRC, 2001). Dairy cow diets fed in the United States typically contain between 20 and 30\% starch on DM basis. Corn is the most commonly used grain for providing starch in lactating dairy cow diets. Because of its high starch content, corn permits the formulation of energy-dense diets required by high-producing dairy cows and promotes microbial protein synthesis in the rumen. However, increasing dietary starch from corn grain at the expense of forage fiber has been demonstrated to negatively affect rumen function. Excess fermentation of starch to VFA in the rumen disturbs the buffering and absorptive capacity of cows, leading to decreased ruminal $\mathrm{pH}$. Feeding less forage NDF also decreases chewing, which reduces saliva production and the passage of its buffers into the rumen. As a result, lower ruminal $\mathrm{pH}$ may decrease appetite, fiber digestion, microbial yield, and milk fat concentration (Mould et al., 1983; Strobel and Russell, 1986; Kalscheur et al., 1997).

Corn grain is used for food, feed, and the growing biofuel industry. This competition for corn has tightened the supply that is available for livestock feed and, as a result, has increased feed costs. The partial replacement of starch with cost-effective, low-starch, nonforage fiber sources represents a potential alternative to help overcome these issues. Previous research conducted on partial substitution of starch with nonforage fiber sources such as soyhulls (SH; Bernard and McNeill, 1991; Ipharraguerre et al., 2002; Aikman et al., 2006), beet pulp (Clark and Armentano, 1997; Voelker and Allen, 2003), and citrus pulp (Leiva et al., 2000) has led to the replacement of significant portions of starch from dairy cow diets.

Dried distillers grains with solubles (DDGS) are a coproduct of the ethanol industry and are traditionally fed as a protein supplement as an alternative to soybean meal. They have been recognized as an excellent source of energy, attributed to their high concentration of digestible NDF and fat (Schingoethe et al., 2009). Dried distillers grains with solubles have been fed suc- 
cessfully up to $20 \%$ of DM in lactating dairy cow diets, maintaining high milk production without impairing DMI (Anderson et al., 2006; Kleinschmit et al., 2006; Schingoethe et al., 2009). Utilization of DDGS as an energy source to replace starch supplied by corn has not been reported previously. We hypothesized that replacing starch with nonforage fiber from DDGS and $\mathrm{SH}$ as energy sources would not affect performance of lactating dairy cows. Therefore, the primary objective was to replace starch provided by corn with nonforage fiber provided by DDGS and SH in dairy cow diets in order to evaluate feed intake, milk production, and milk composition. A secondary objective was to determine the cost-effectiveness of feeding diets in which nonforage fiber replaced starch.

\section{MATERIALS AND METHODS}

\section{Animals and Diets}

This experiment was conducted at the Dairy Research and Training Facility at South Dakota State University (Brookings), and all procedures were approved by the South Dakota Institutional Animal Care and Use Committee. Forty Holstein cows $[22$ multiparous (77 \pm 33 DIM) and 18 primiparous $(79 \pm 29$ DIM)] were assigned to 4 treatments (10 cows each) in a completely randomized design. All cows were fed a common diet for 2 wk (covariate period) followed by the experimental diets for 6 wk (experimental period). Diets were formulated to meet or exceed NRC (2001) requirements for mature, lactating Holstein cows of $614 \mathrm{~kg}$ of BW, at $60 \mathrm{DIM}$, producing $41 \mathrm{~kg}$ of milk. Formulated diets were to provide decreasing concentrations of starch [29, 26, 23, and 20\% (DM basis)]; ground corn, solventextracted soybean meal, and expeller soybean meal were replaced by increasing concentrations of DDGS and SH (Table 1). The DDGS were purchased from a South Dakota ethanol plant (Glacial Lakes Energy LLC, Watertown) as a single shipment to ensure similar composition throughout the experiment. Corn silage and alfalfa were forage sources and composed 27 and $22 \%$ of diet DM, respectively, in all diets. Ruminally inert fat (Energy Booster, Milk Specialties Co., Dundee, IL) was added to all diets to increase crude fat level and to maintain similar fat concentrations for all diets (4.7\%). Inclusion of the ruminally inert fat decreased from 1.38 to $0.35 \%$ as DDGS increased from 0 to $21 \%$. Forages were premixed in a vertical mixer and blended with concentrates in a Calan Data Ranger (American Calan Inc., Northwood, NH). Cows were fed diets as a TMR once daily $(0800 \mathrm{~h})$ using the Calan Broadbent feeder door system (American Calan Inc.). Diets were adjusted to allow for ad libitum intake (10\% orts).
Cows had unlimited access to feed and water, except during milking.

\section{Measurements and Sampling Procedures}

Feed offered and refused was recorded daily using a Calan Data Ranger (American Calan Inc.). Dry matter intake was measured individually for the 10 cows of each of the 4 treatment groups using data on daily feed offered and refused. Samples of corn silage, alfalfa, concentrate mixes, diets, and orts were collected on d 7 of each week of the experiment and stored at $-20^{\circ} \mathrm{C}$ until analyzed. Samples of ground corn, soybean meal, expellers soybean meal (SoyPlus, West Central Soy, Ralston, IA), DDGS, SH, and a rumen-inert fat were collected 3 times when concentrates were mixed at the feed mill. All other feed samples were composited into 2-wk periods.

Cows were milked thrice daily at 0600, 1400, and $2100 \mathrm{~h}$, and milk production was recorded. Milk samples were collected from each milking on 3 consecutive days at the end of the covariate period and during wk 6 of the experimental period and once each week from wk 1 to 5.

The BW and BCS of each cow were recorded on the last $3 \mathrm{~d}$ of the covariate period and on the last $3 \mathrm{~d}$ at the end of the experiment. Body condition scores were recorded independently by 3 individuals on a scale of 1 to 5 , where 1 represented emaciated and 5 represented obese (Wildman et al., 1982).

Blood was collected by venipuncture of the coccygeal artery (arterial sample) approximately $3 \mathrm{~h}$ after feeding during the covariate period and wk 2, 4, and 6 of the experiment period. Blood was drawn into $10-\mathrm{mL}$ evacuated tubes containing $\mathrm{K}_{3}$-EDTA anticoagulant (Becton Dickinson and Co., Rutherford, NJ).

Rumen fluid samples were aspirated with an esophageal tube and a hand-operated pump approximately 3 $\mathrm{h}$ after feeding on the last 2 consecutive days of wk 6 of the experimental period. After discarding the initial draw of $200 \mathrm{~mL}$ to minimize potential saliva contamination, a $10-\mathrm{mL}$ aliquot of rumen fluid was acidified with $2 \mathrm{~mL}$ of $25 \%$ (wt/vol) metaphosphoric acid according to Erwin et al. (1961) and transported on ice to the laboratory. Samples were frozen at $-20^{\circ} \mathrm{C}$ until analysis.

\section{Laboratory Analyses}

All feed samples were dried at $55^{\circ} \mathrm{C}$ for $48 \mathrm{~h}$ in a Despatch oven (style V-23, Despatch Oven Co., Minneapolis, MN). The dried composites were ground to 2-mm particle size (Wiley mill, model 3, Arthur H. Thomas Co., Philadelphia, PA) and then further ground 
Table 1. Composition of ingredients, nutrients, and fatty acids of diets with decreasing concentrations of dietary starch fed to cows

\begin{tabular}{|c|c|c|c|c|}
\hline \multirow[b]{2}{*}{ Item } & \multicolumn{4}{|c|}{$\operatorname{Diet}^{1}$} \\
\hline & $29 \%$ & $26 \%$ & $23 \%$ & $20 \%$ \\
\hline \multicolumn{5}{|l|}{ Ingredient ( $\%$ of DM) } \\
\hline Corn silage & 26.9 & 26.9 & 26.9 & 26.9 \\
\hline Alfalfa hay & 22.1 & 22.1 & 22.1 & 22.1 \\
\hline Ground corn & 35.0 & 29.3 & 23.6 & 17.9 \\
\hline Dried distillers grains with solubles & 0 & 7.0 & 14.0 & 21.0 \\
\hline Soybean hulls & 0 & 3.19 & 6.36 & 9.55 \\
\hline Soybean meal, $44 \%$ CP & 4.53 & 3.21 & 1.89 & 0.56 \\
\hline Expellers soybean meal $^{2}$ & 8.43 & 5.61 & 2.82 & 0 \\
\hline Ruminally inert fat $^{3}$ & 1.38 & 1.04 & 0.70 & 0.35 \\
\hline Limestone & 0.80 & 0.80 & 0.80 & 0.80 \\
\hline Salt & 0.40 & 0.40 & 0.40 & 0.40 \\
\hline Dicalcium phosphate & 0.30 & 0.30 & 0.30 & 0.30 \\
\hline Dairy micro premix ${ }^{4}$ & 0.20 & 0.20 & 0.20 & 0.20 \\
\hline \multicolumn{5}{|l|}{ Nutrient ( $\%$ of DM unless noted) } \\
\hline $\mathrm{DM}(\%$ of diet) & 48.5 & 47.8 & 47.6 & 48.4 \\
\hline $\mathrm{OM}$ & 93.0 & 93.1 & 93.1 & 93.2 \\
\hline $\mathrm{CP}$ & 16.8 & 16.7 & 16.5 & 16.7 \\
\hline $\mathrm{NDF}$ & 28.4 & 31.1 & 34.3 & 36.4 \\
\hline NDF from forage & 22.9 & 22.9 & 22.9 & 22.9 \\
\hline $\mathrm{ADF}$ & 16.1 & 17.5 & 19.6 & 20.5 \\
\hline $\mathrm{NFC}^{5}$ & 43.5 & 40.2 & 36.9 & 34.6 \\
\hline Starch & 29.0 & 26.0 & 23.1 & 19.9 \\
\hline Crude fat & 4.35 & 5.07 & 5.37 & 5.48 \\
\hline Ash & 6.99 & 6.95 & 6.88 & 6.83 \\
\hline $\mathrm{Ca}$ & 0.93 & 0.93 & 0.94 & 0.97 \\
\hline $\mathrm{P}$ & 0.37 & 0.38 & 0.39 & 0.40 \\
\hline $\mathrm{Mg}$ & 0.27 & 0.29 & 0.29 & 0.30 \\
\hline $\mathrm{K}$ & 1.26 & 1.26 & 1.26 & 1.26 \\
\hline $\mathrm{S}$ & 0.16 & 0.17 & 0.19 & 0.21 \\
\hline $\mathrm{NE}_{\mathrm{L}}^{6}(\mathrm{Mcal} / \mathrm{kg})$ & 1.70 & 1.68 & 1.65 & 1.63 \\
\hline \multicolumn{5}{|l|}{ Fatty acid (g/100 $\mathrm{g}$ of total fatty acids) } \\
\hline C14:0 & 0.86 & 0.73 & 0.79 & 0.82 \\
\hline C16:0 & 25.6 & 23.1 & 20.7 & 18.4 \\
\hline C16:1 trans -9 & 0.42 & 0.41 & 0.38 & 0.37 \\
\hline C16:1 cis-9 & 0.21 & 0.18 & 0.16 & 0.17 \\
\hline $\mathrm{C} 17: 0$ & 0.70 & 0.55 & 0.41 & 0.29 \\
\hline C18:0 & 13.8 & 10.8 & 7.8 & 5.1 \\
\hline C18:1 total & 15.4 & 17.7 & 18.6 & 20.1 \\
\hline C18:2 trans- 9, trans -12 & 0.28 & 0.25 & 0.27 & 0.25 \\
\hline C18:2 cis-9,cis-12 & 27.1 & 31.2 & 35.1 & 38.3 \\
\hline $\mathrm{C} 18: 3 n-3$ & 7.6 & 7.2 & 7.5 & 7.4 \\
\hline C20:0 & 0.52 & 0.54 & 0.51 & 0.51 \\
\hline $\mathrm{C} 20: 1$ & 0.14 & 0.14 & 0.14 & 0.17 \\
\hline $\mathrm{C} 20: 2$ & 0.29 & 0.28 & 0.26 & 0.44 \\
\hline $\mathrm{SFA}^{7}$ & 42.0 & 36.3 & 30.7 & 25.8 \\
\hline $\mathrm{UFA}^{8}$ & 58.0 & 63.6 & 69.3 & 74.2 \\
\hline Total fatty acids (g/100 g of DM) & 4.1 & 4.1 & 4.5 & 4.8 \\
\hline
\end{tabular}

${ }^{1}$ Diets provided decreasing concentrations of starch: $29 \%$ starch with $0 \%$ dried distillers grains with solubles (DDGS); $26 \%$ starch with 7\% DDGS; $23 \%$ starch with 14\% DDGS; and 20\% starch with $21 \%$ DDGS.

${ }^{2}$ SoyPlus (West Central Soy, Ralston, IA).

${ }^{3}$ Energy Booster (Milk Specialties Co., Dundee, IL).

${ }^{4}$ Contained: $10 \% \mathrm{Mg} ; 2.6 \% \mathrm{Zn} ; 1.7 \mathrm{mg} / \mathrm{kg}$ of $\mathrm{Mn} ; 4,640 \mathrm{mg} / \mathrm{kg}$ of Fe; $4,712 \mathrm{mg} / \mathrm{kg}$ of Cu; $396 \mathrm{mg} / \mathrm{kg}$ of I; 119 $\mathrm{mg} / \mathrm{kg}$ of Co; $140 \mathrm{mg} / \mathrm{kg}$ of Se; 2,640,000 IU/ $\mathrm{kg}$ of vitamin A; 528,000 IU/kg of vitamin $\mathrm{D}_{3}$; and 10,560 IU $/ \mathrm{kg}$ of vitamin E (Land O'Lakes, St. Paul, MN).

${ }^{5} \mathrm{NFC}=100-(\% \mathrm{NDF}+\% \mathrm{CP}+\%$ crude fat $+\%$ ash $)(\mathrm{NRC}, 2001)$.

${ }^{6}$ Calculated according to NRC (2001) using analyzed feed values.

${ }^{7} \mathrm{SFA}=$ total concentration of saturated fatty acids.

${ }^{8} \mathrm{UFA}=$ total concentration of unsaturated fatty acids 
to 1-mm particle size using an ultracentrifuge mill (Brinkman Instruments Co., Westbury, NY). Ground samples were analyzed for DM, ash, CP, NDF, ADF, crude fat, starch, minerals, and fatty acid composition. Dry matter was determined at $105^{\circ} \mathrm{C}$ for $3 \mathrm{~h}$ (Shreve et al., 2006). Ash was determined at $450^{\circ} \mathrm{C}$ for $8 \mathrm{~h}$ (Undersander et al., 1993). Crude protein was determined using the Kjeldahl procedure as described in AOAC (2002). Concentrations of NDF (Van Soest et al., 1991) and ADF (Robertson and Van Soest, 1981) were determined sequentially using the Ankom fiber analysis system (Ankom Technology, Macedon, NY). $\alpha$-Amylase (Ankom Technology) and sodium sulfite were used for the NDF procedure. Crude fat was analyzed with an Ankom ${ }^{\mathrm{X} 10}$ Extractor (Ankom Technology) using diethyl ether according to AOCS (2004) procedures. Starch concentrations were determined using an enzyme-based (thermostable $\alpha$-amylase and amyloglucosidase) total starch assay (AOAC, 2002; Total Starch Assay Procedure, Megazyme International Ireland Ltd., Wicklow, Ireland). Composites of corn silage, alfalfa hay, DDGS, and diets were sent to Dairyland Laboratories Inc. (Arcadia, WI) for mineral analysis ( $\mathrm{Ca}, \mathrm{P}, \mathrm{K}, \mathrm{Mg}$, and $\mathrm{S}$ ). Minerals were quantified according to AOAC (2002) using an inductively coupled plasma spectrometer (Thermo Jarrell Ash, Franklin, MA). Feed fatty acids were prepared as butyl esters according to Abdelqader et al. (2009). Prepared samples were then analyzed using gas chromatography (model 6890, Hewlett-Packard, Palo Alto, CA). The injector port was at $230^{\circ} \mathrm{C}$ with a split ratio of 100:1. The column was $100 \mathrm{~m}$ in length with an inside diameter of $0.25 \mathrm{~mm}$ (Supelco 2560, Supelco Inc., Bellefonte, PA). Flow-rate was $2.0 \mathrm{~mL} /$ min of helium. Initial temperature of the column was $50^{\circ} \mathrm{C}$ and held for $5 \mathrm{~min}$, then increased to $145^{\circ} \mathrm{C}$ at a rate of $5^{\circ} \mathrm{C} / \mathrm{min}$. It was held at $145^{\circ} \mathrm{C}$ for $30 \mathrm{~min}$, then increased to $190^{\circ} \mathrm{C}$ at $10^{\circ} \mathrm{C} / \mathrm{min}$ to hold the temperature for $30 \mathrm{~min}$. Finally, the temperature was increased at $5^{\circ} \mathrm{C} / \mathrm{min}$ to $210^{\circ} \mathrm{C}$ and held at this temperature for $40 \mathrm{~min}$. Individual fatty acids were identified by order of elution and comparison to known, commercially prepared reference standards (GLC-606 and GLC-566, Nu-Chek Prep Inc., Elysian, MN).

The 4-screen Penn State Particle Size Separator (PSPS; Kononoff et al., 2003) was used to determine the particle size distribution of each diet and orts. The DM and NDF were determined on the particles retained on each sieve. The physical effectiveness factor (pef) was calculated as the proportion of particles retained (DM basis) on the top 2 screens (pef $_{\mathrm{ps}-2 \mathrm{~s}}$; Lammers et

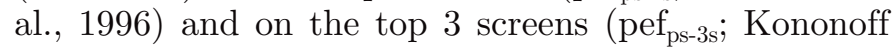
et al., 2003). Physically effective NDF (peNDF ${ }_{P S}$ ) was calculated as dietary NDF multiplied by pef.
The collected milk samples were composited by day on a weight basis proportional to yield and separated into 2 aliquots. The first aliquot was sent to Heart of America DHIA Laboratory (Manhattan, KS) for milk composition analysis. Mid-infrared spectroscopy (Bentley 2000 Infrared Milk Analyzer, Bentley Instruments, Chaska, MN; AOAC, 2002) was used to analyze milk fat, protein, and lactose, whereas MUN concentration was determined using chemical methodology based on a modified Berthelot reaction (ChemSpec 150 Analyzer, Bentley Instruments). Somatic cell counts were determined using a flow cytometer laser (Somacount 500, Bentley Instruments; AOAC, 2002). Somatic cell counts were converted to SCS where SCS $=\log _{10}(\mathrm{SCC})$. Energy-corrected milk was determined using the following equation: $\{[0.327 \times$ milk yield $(\mathrm{kg})]+[12.95 \times$ fat yield $(\mathrm{kg})]+[7.2 \times$ protein yield $(\mathrm{kg})]\}$ (Orth, 1992). A second aliquot of milk samples collected at the end of the covariate period and wk 6 of the experimental period was analyzed for fatty acid composition. Milk fatty acids were prepared as described by Abdelqader et al. (2009) and analyzed by gas chromatography as described above.

The collected blood samples were immediately placed in ice and taken to the laboratory, where they were centrifuged $(500 \times g)$ for 20 min to separate the plasma. The plasma was stored at $-20^{\circ} \mathrm{C}$ until analysis. Plasma samples were thawed and analyzed for glucose using glucose oxidase (glucose kit, cat. no. G7521, Pointe Scientific, Canton, MI) according to Trinder (1969). Concentration of BHBA in plasma was determined (BHBA kit, cat. no. H7587-58, Pointe Scientific) following the methods of Williamson et al. (1962).

Ruminal samples were thawed and centrifuged at $30,000 \times g$ for $20 \mathrm{~min}$. Concentrations of VFA were measured using an automated gas-liquid chromatograph (model 6890, Hewlett-Packard) using a flameionization detector. Volatile fatty acids were separated on a capillary column $(15 \mathrm{~m} \times 0.25 \mathrm{~mm}$ i.d.; Nukol, 17926-01C, Supelco Inc., Bellefonte, PA) using 2-ethylbutyrate as an internal standard. The split ratio of 100:1 in the injector port was at a temperature of $250^{\circ} \mathrm{C}$ with flow-rate of $1.3 \mathrm{~mL} / \mathrm{min}$ of He. The column and detector temperature were maintained at $140^{\circ} \mathrm{C}$ and $250^{\circ} \mathrm{C}$, respectively.

\section{Data Analyses}

Weekly means for feed intake, milk yield, milk composition, and particle size were used for statistical analysis. All data were analyzed by the MIXED procedure in SAS (SAS, 2001) in a completely randomized design. The model for feed intake, milk yield, milk composi- 
tion, and blood parameters was $\mathrm{Y}=$ covariate period + treatment + parity + week $+($ treatment $\times$ parity $)$ $+($ treatment $\times$ week $)+($ parity $\times$ week $)+($ treatment $x$ parity $x$ week), where the random effect was cow nested within treatment and parity. The model for the particle size data was $\mathrm{Y}=$ treatment + week + (treatment $\times$ week). The model for fatty acid data was $\mathrm{Y}=$ covariate period + treatment + parity + (treatment $\times$ parity), where the random effect was cow nested within treatment and parity. The same model was used for rumen measures, BW change, and BCS change, except that there was no covariate period. Week was used as repeated measures when included in the model with the covariance structure corresponding to the lowest value according to the Akaike's information criterion being selected (Littell et al., 2006). Nonsignificant interactions were sequentially dropped from the model. Significant interactions are identified in the results and tables. Least squares means are reported for each variable. Polynomial orthogonal contrasts were used to test the linear, quadratic, and cubic effects of decreasing inclusion of dietary starch. Statistical significance of main effects was declared at $P \leq 0.05$, and tendencies were discussed at $0.05 \leq P \leq 0.10$.

An economic analysis was conducted to compare the income over feed cost (IOFC) of diets using the following formula: IOFC $=(\$ /$ cow per $\mathrm{d})=$ all-milk price $(\$ / \mathrm{kg}) \times$ daily average milk production $(\mathrm{kg} / \mathrm{cow}$ per day) - daily feed cost (\$/cow per day). Six-year average prices (2003-2008) were used for corn silage $(\$ 31.50 / \mathrm{t})$, alfalfa hay $(\$ 128.00 / \mathrm{t})$, ground corn $(\$ 0.12 /$ $\mathrm{kg})$, soybean meal $(\$ 0.26 / \mathrm{kg})$, expellers soybean meal $(\$ 0.34 / \mathrm{kg})$, DDGS $(\$ 0.13 / \mathrm{kg}), \mathrm{SH}(\$ 0.10 / \mathrm{kg})$, rumeninert fat $(\$ 1.21 / \mathrm{kg})$, dicalcium phosphate $(\$ 0.36 / \mathrm{kg})$, dairy micro premix $(\$ 0.82 / \mathrm{kg})$, limestone $(\$ 0.05 / \mathrm{kg})$, and salt $(\$ 0.16 / \mathrm{kg})$. Price of corn silage was calculated as the price of corn grain/bushel $\times 10$. Prices of corn grain and alfalfa hay were obtained from Economic Research Service (USDA, 2009), and prices of all other ingredients were obtained from the South Dakota State University Feed Processing Unit (Brookings). Milk component prices were calculated from South Dakota State University Dairy Research and Training Facility from 2003 to 2008. Six-year average prices of milk fat, protein, and other solids were $\$ 3.47 / \mathrm{kg}, \$ 6.27 / \mathrm{kg}$, and $\$ 0.24 / \mathrm{kg}$, respectively.

\section{RESULTS AND DISCUSSION}

\section{Dietary Nutrient Composition}

The chemical composition of all diets, concentrate mixes, corn silage, alfalfa hay, DDGS, ground corn, and $\mathrm{SH}$ used in the experiment are presented in Tables 1 and 2. Crude protein concentration was similar across diets, and all values were similar to the formulated CP concentration of $17.0 \%$. As expected, NDF and ADF concentration increased numerically with higher DDGS and $\mathrm{SH}$ in the diets. Starch concentration in the diets decreased from 29 to $20 \%$ as corn was removed. Diets were also formulated to have similar concentrations of crude fat $(4.7 \%)$, but crude fat increased from 4.35 to $5.48 \%$ of the diet DM as DDGS was included in the diets. This resulted from DDGS having a slightly greater concentration of fat $(13.8 \%)$ than the value used in the original formulation (10.3\%). Mineral concentrations were similar except for $\mathrm{S}$, which numerically increased from 0.16 to $0.21 \%$ as DDGS were included.

Total fatty acids numerically increased from 4.1 to $4.8 \%$, the result of ingredient changes as starch decreased from 29 to $20 \%$ in the diets (Table 1). Fatty acid composition changed across diets (Table 1); C16:0 and C18:0 numerically decreased and C18:1 and C18:2 increased as corn was replaced with DDGS and SH. Changes in fatty acid composition can be explained by reviewing the fatty acid profiles of individual dietary ingredients. Ruminally inert fat and DDGS were the main ingredients that affected fatty acid profiles of diets. Because ruminally inert fat contained a greater proportion of saturated fatty acids, particularly C16:0 and C18:0, a greater concentration of saturated fatty acids was observed in the higher starch diets. Conversely, unsaturated fatty acid concentration was greater in DDGS; therefore, more unsaturated fatty acids were observed in diets with greater DDGS inclusion.

\section{Dietary Particle Size}

Feed particles separation using the PSPS (Table 3) showed that, for all diets, the top screen retained an average of $9.1 \%$ on as-fed basis and $8.0 \%$ when corrected for DM. The separations based on as-fed basis demonstrated that, on one hand, the proportion of particles retained on the top 2 screens linearly decreased as diets increased in nonforage NDF and decreased in starch concentration. On the other hand, particles retained on the third screen increased when the concentration of nonforage fiber increased, but there was no difference across diets for particles remaining in the bottom pan. On a DM basis, particles retained on the top screen were similar across all diets, probably because all diets contained similar amounts of forage. Particles retained on the second screen increased quadratically $(P=0.05)$ when starch from corn was removed from the diets. The portion of the diet remaining on the third screen increased linearly $(P<0.001)$ and on the bottom pan decreased linearly $(P<0.001)$ as nonforage fibers replaced starch. This evolution contributed to an increase 
Table 2. Composition of nutrients and fatty acids of concentrate mixes, corn silage, alfalfa hay, dried distillers grains with solubles (DDGS), ground corn, soy hulls, and ruminally inert fat used in diets during the lactation study

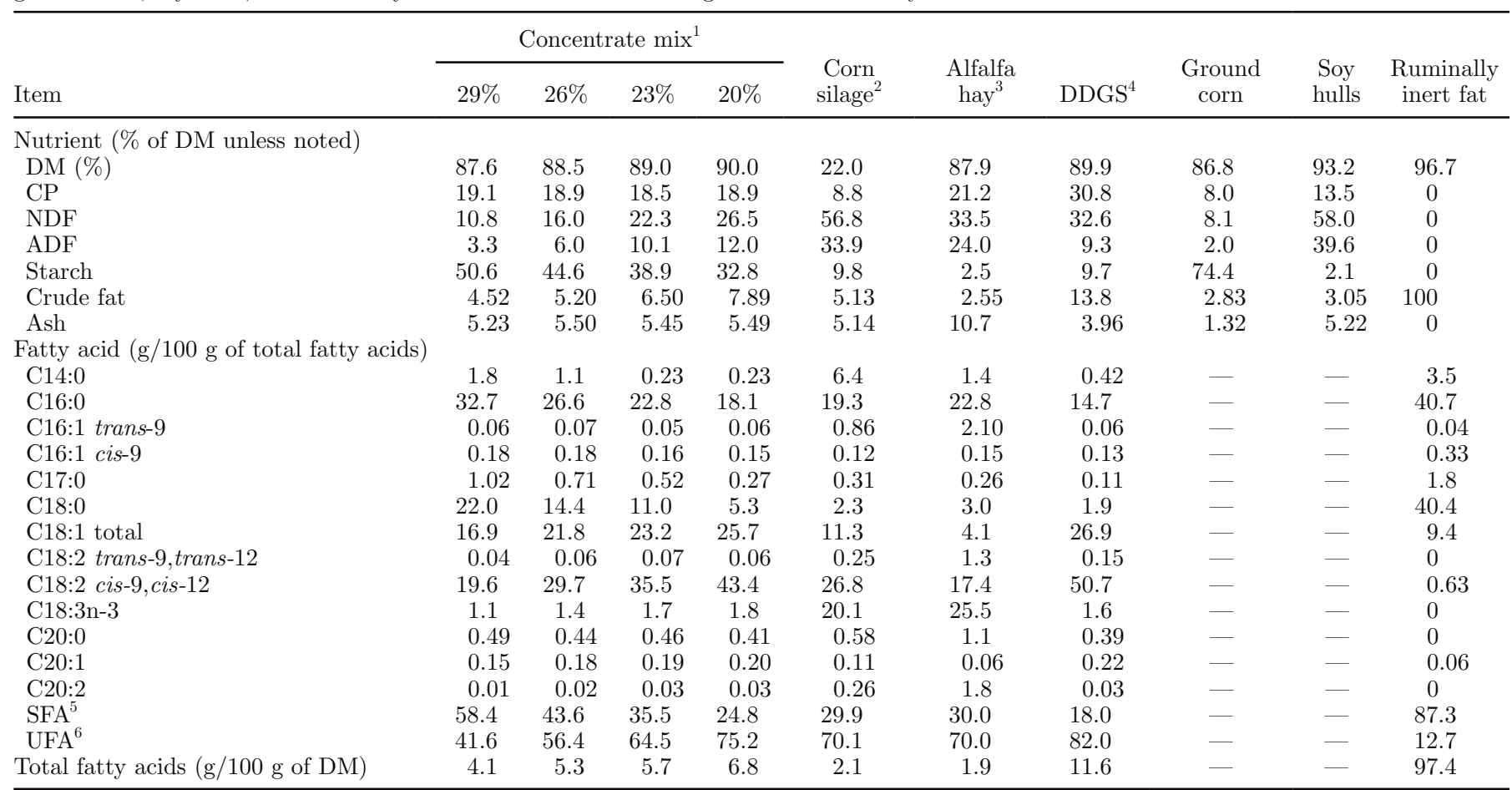

${ }^{1}$ Concentrate mixes of diets that provided decreasing concentrations of starch: $29 \%$ starch with $0 \%$ DDGS; $26 \%$ starch with $7 \%$ DDGS; $23 \%$ starch with $14 \%$ DDGS; and $20 \%$ starch with $21 \%$ DDGS.

${ }^{2}$ Mineral analysis of corn silage: $0.26 \% \mathrm{Ca}, 0.23 \% \mathrm{P}, 0.26 \% \mathrm{Mg}, 1.11 \% \mathrm{~K}$, and $0.10 \% \mathrm{~S}$.

${ }^{3}$ Mineral analysis of alfalfa hay: $1.55 \% \mathrm{Ca}, 0.28 \% \mathrm{P}, 0.35 \% \mathrm{Mg}, 2.02 \% \mathrm{~K}$, and $0.18 \% \mathrm{~S}$.

${ }^{4}$ Mineral analysis of DDGS: $0.06 \% \mathrm{Ca}, 0.69 \% \mathrm{P}, 0.30 \% \mathrm{Mg}, 0.86 \% \mathrm{~K}$, and $0.51 \% \mathrm{~S}$.

${ }^{5} \mathrm{SFA}=$ total concentration of saturated fatty acids.

${ }^{6} \mathrm{UFA}=$ total concentration of unsaturated fatty acids.

in the proportion of particles greater than the critical value of $1.18 \mathrm{~mm}$; this was probably the result of $\mathrm{SH}$ inclusion because DDGS typical mean particle size is smaller than $1.18 \mathrm{~mm}$ (Kleinschmit et al., 2007).

The NDF concentrations for each fraction from PSPS showed that it was greatest in the fraction obtained from the top 2 screens. The NDF concentrations of the fractions obtained from the third screen and bottom pan linearly increased as starch decreased in the diets. The physical effectiveness factor $\left(\right.$ pef $\left._{\mathrm{ps}-2 \mathrm{~s}}\right)$ was similar across all diets when calculated using the fractions obtained from the top and second screens. However, there was a linear increase $(P<0.001)$ for the pef $_{\mathrm{ps}-3 \mathrm{~s}}$ as DDGS and SH replaced corn in the diets. A similar pattern was observed for peNDF. Physically effective NDF increased linearly $(P<0.001)$ as DDGS and SH replaced corn in the diets. Differences in calculated pef across diets further explained the effective fiber contribution of the byproduct's fiber portion. The particle size distribution, pef, and peNDF were also determined on the orts of each diet (data not shown for particle size distribution of orts). Measurements for the orts samples were very similar to the numbers reported for the TMR diets, indicating no significant sorting occurred during the experiment. This indicated that diets used in this experiment were properly mixed and that nutrient intake was not influenced by particle size.

\section{Rumen Fluid and Blood Analysis}

Decreasing dietary starch concentration did not change total VFA concentration (Table 4). Molar proportions of acetate linearly decreased $(P=0.03)$ when dietary starch was replaced with nonforage fiber; however, molar proportions of other VFA, including propionate, butyrate, valerate, isobutyrate, and isovalerate, were similar across all diets. The observed linear decrease of acetate concentration with greater DDGS and SH concentrations in the diets was probably attributable to decreased forage NDF intake or greater concentration of unsaturated fatty acids in the diets with greater DDGS concentration. There was a linear decrease $(P=0.04)$ in the acetate:propionate ratio, resulting primarily from the linear decrease in acetate 
Table 3. Particle size distribution, physical effectiveness factor (pef), and physically effective NDF of diets with decreasing concentrations of dietary starch

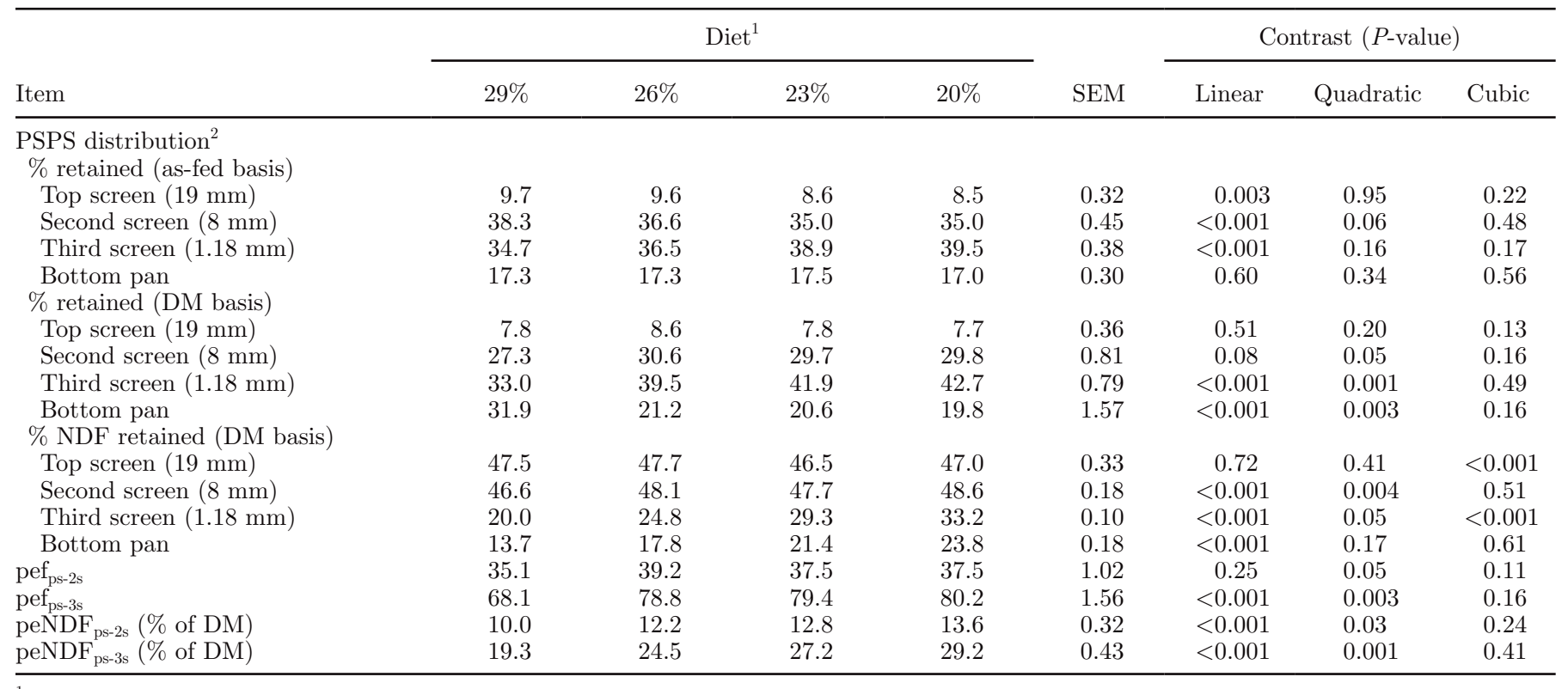

${ }^{1}$ Diets provided decreasing concentrations of starch: $29 \%$ starch with $0 \%$ dried distillers grains with solubles (DDGS); $26 \%$ starch with $7 \%$ DDGS; $23 \%$ starch with $14 \%$ DDGS; and 20\% starch with 21\% DDGS.

${ }^{2}$ Particle size distribution of diets was measured using Penn State Particle Separator (PSPS; Kononoff and Heinrichs, 2003); pef $f_{\mathrm{ps}-2 \mathrm{~s}}$ and pef $\mathrm{ps}_{\mathrm{ps}-3 \mathrm{~s}}$ $=$ physical effectiveness factor determined as the proportion of particles retained on 2 sieves (Lammers et al., 1996) and 3 sieves (Kononoff and Heinrichs, 2003), respectively; $\mathrm{peNDF}_{\mathrm{ps}-2 \mathrm{~s}}$ and $\mathrm{peNDF}_{\mathrm{ps}-3 \mathrm{~s}}=$ physically effective NDF determined as dietary NDF content multiplied by pef $\mathrm{ps}_{2 \mathrm{~s}}$ and pef $\mathrm{ps}_{\mathrm{ss}}$, respectively.

concentration, when starch was replaced with nonforage fiber in the diets. There was no treatment effect on either the plasma glucose or BHBA (Table 4). Average concentration of plasma glucose and BHBA concentrations were 64.7 and $8.5 \mathrm{mg} / \mathrm{dL}$, respectively.

\section{Intake, BW, and BCS}

Nutrient intakes, BW, and BCS of cows during the experiment are presented in Table 5. Dry matter in- take decreased linearly $(P=0.005)$ when DDGS and SH replaced corn, with the highest DMI recorded for the $29 \%$ starch diet $(25.6 \mathrm{~kg} / \mathrm{d})$ and the lowest for the $20 \%$ starch diet $(22.9 \mathrm{~kg} / \mathrm{d})$. Previous experiments have reported a variety of DMI responses to the substitution of nonforage fiber for starch. In agreement with our findings, DMI was reduced with increasing $\mathrm{SH}$ in Ipharraguerre et al. (2002) and Aikman et al. (2006). Conversely, DMI was not affected by increasing SH, with dietary NDF increasing from 31 to $57.6 \%$ and

Table 4. Ruminal volatile fatty acids (VFA) concentrations and plasma metabolites of cows fed diets with decreasing concentrations of dietary starch

\begin{tabular}{|c|c|c|c|c|c|c|c|c|}
\hline Item & \multicolumn{4}{|c|}{$\operatorname{Diet}^{1}$} & SEM & \multicolumn{3}{|c|}{ Contrast ( $P$-value $)$} \\
\hline \multicolumn{8}{|l|}{ VFA (mmol/100 mmol) } & 0.96 \\
\hline Acetate & 61.8 & 61.9 & 61.9 & 60.7 & 0.30 & 0.03 & 0.06 & 0.46 \\
\hline Propionate & 17.1 & 17.0 & 17.1 & 18.0 & 0.42 & 0.12 & 0.74 & 0.45 \\
\hline Butyrate & 11.5 & 11.4 & 11.5 & 11.6 & 0.13 & 0.41 & 0.36 & 0.83 \\
\hline Acetate:propionate & 3.63 & 3.67 & 3.63 & 3.37 & 0.09 & 0.04 & 0.11 & 0.72 \\
\hline \multicolumn{9}{|l|}{ Plasma metabolites } \\
\hline Glucose (mg/dL) & 65.7 & 63.0 & 65.7 & 64.2 & 2.3 & 0.87 & 0.79 & 0.31 \\
\hline $\mathrm{BHBA}(\mathrm{mg} / \mathrm{dL})$ & 8.5 & 8.6 & 8.1 & 8.7 & 0.4 & 0.92 & 0.55 & 0.41 \\
\hline
\end{tabular}

${ }^{1}$ Diets provided decreasing concentrations of starch: $29 \%$ starch with $0 \%$ dried distillers grains with solubles (DDGS); $26 \%$ starch with $7 \%$ DDGS; $23 \%$ starch with $14 \%$ DDGS; and 20\% starch with $21 \%$ DDGS. 
Table 5. Nutrient intake, BW, BCS, milk yield, milk composition, and feed efficiency of cows fed diets with decreasing concentrations of dietary starch

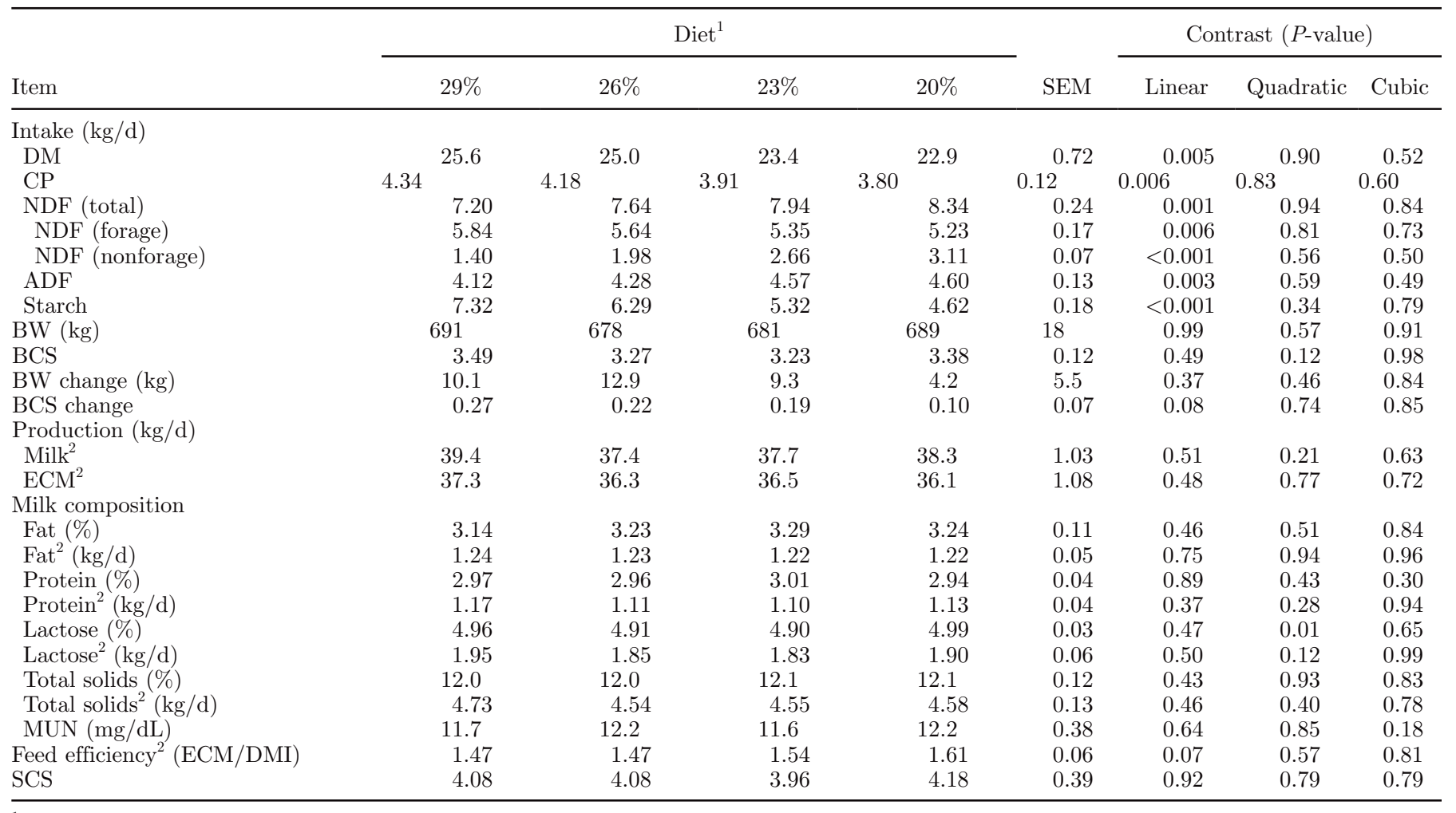

${ }^{1}$ Diets provided decreasing concentrations of starch: $29 \%$ starch with $0 \%$ dried distillers grains with solubles (DDGS); $26 \%$ starch with $7 \%$ DDGS; $23 \%$ starch with $14 \%$ DDGS; and $20 \%$ starch with $21 \%$ DDGS.

${ }^{2}$ Interaction of parity $\times$ week $(P<0.05)$.

NSC decreasing from 47 to $22 \%$ in Nakamura and Owen (1989), Sarwar et al. (1992), and Mansfield and Stern (1994). Nakamura and Owen (1989) hypothesized that SH dietary inclusion may improve the digestion or the passage rate or a combination of both. This effect could have counteracted the increase of NDF above $32 \%$, which is suggested to be the limit above which NDF depresses DMI (Mertens, 1994).

The reasons for the decrease of DMI with increasing nonforage fiber as observed in the present results are varied. Factors such as total NDF, fiber effectiveness, forage NDF concentration, source of nonforage fiber, and other characteristics (i.e., water-holding capacity, specific gravity, rumen degradability, or fatty acid composition of the diet) might affect DMI. Firkins (1997) suggested that decreasing the forage NDF concentration to less than 14 to $16 \%$ of the total DM might also decrease DMI when fibrous byproducts are included in the diets. This decrease in DMI could be attributed to a factor such as decreasing the effectiveness of those diets to stimulate rumination and salivation. In addition, an accumulation of acids and decreased $\mathrm{pH}$ of ruminal fluid caused by rapid fermentation of the more-digestible fiber from nonforage sources could also decrease DMI (Harmison et al., 1997).

Dietary NDF and DMI are inversely and strongly correlated (Mertens, 1994), but NDF from SH may not restrict DMI to the same extent as NDF from forages (Ipharraguerre and Clark, 2003). On one hand, DMI and NDF correlate negatively when forages are the main or sole source of NDF. On the other hand, $\mathrm{SH}$ contain a pool of potentially degradable NDF greater than that of most forages. Finally, the smaller particle size and higher specific gravity of SH could double the rumen passage rate compared with forages (Ipharraguerre and Clark, 2003). The decrease in DMI observed in the present experiment when substituting grain with high-fiber byproducts may physically limit the rumen fill (Forbes, 1995). In fact, forage NDF was higher than recommended (NRC, 2001) and VFA concentrations were not altered, which cannot relate decreased DMI with changes in VFA. Moreover, DMI should not have been reduced by DDGS in this study because the DMI depression with dietary inclusion of DDGS does not typically occur until their inclusion exceeds 20 to $30 \%$ (Kalscheur, 2005; Anderson et al., 2006; Kleinschmit 
et al., 2006; Sasikala-Appukuttan et al., 2008; Schingoethe et al., 2009). In the present study, the decrease in DMI began with the lowest inclusion of byproducts $(7 \%$ of DDGS $+3.1 \%$ of $\mathrm{SH})$ and continued as additional nonforage fiber replaced starch. The dietary NDF content was $31.1 \%$ or higher for all the diets with byproducts inclusion, which is close to the $32 \%$ level suspected to affect DMI (Mertens, 1994). Consequently, the increased dietary NDF content resulting from the inclusion of byproducts may have filled the rumen, which in turn reduced DMI.

In the present study, inclusion of DDGS in the diets increased the dietary fat concentration from 4.35 to $5.48 \%$ on DM basis, and this led to increased unsaturated fatty acid concentration from 58 to $74.2 \%$ on DM basis. Greater dietary fat concentration can be another possible reason to decrease DMI. Allen et al. (2005) demonstrated that an increase in unsaturated longchain fatty acids has a hypophagic effect that could decrease intake. Therefore, greater unsaturated fatty acid concentration might have stimulated the satiety receptors and decreased DMI. Similar linear decreases in DMI when wet distillers grains and SH replaced corn and soybean meal have been observed in a study conducted on growing Holstein heifers (Anderson et al., 2009).

All the diets contained the same dietary amounts of CP $(17 \%)$ and forage NDF $(22.9 \%)$, but as shown in Table 5, the decrease in DMI also linearly decreased CP and forage NDF intakes $(P=0.006)$. Conversely, total NDF, nonforage NDF, and total ADF intakes increased linearly $(P<0.01)$. As expected, starch intake decreased linearly $(P<0.001)$ according to diet formulation. Starch intake decreased $2.7 \mathrm{~kg} / \mathrm{d}$ when dietary starch decreased from 29 to $20 \%$. Average BW of cows during the experiment was $685 \mathrm{~kg}$, and there was no treatment effect on BW. Average BCS varied from 3.27 to 3.49, but no differences were observed for BCS when diets varied in starch concentration. There were no observed BW changes during the experimental period, but there was a tendency $(P=0.08)$ for change in BCS for cows fed diets containing lower starch concentrations.

\section{Milk Production and Composition}

Milk production averaged $38.2 \mathrm{~kg} / \mathrm{d}$ per cow for all treatments (Table 5) and was not affected by starch replacement with nonforage fiber in the diets. A parity $\times$ week interaction $(P<0.05)$ was observed for milk yield because primiparous cows were more persistent in production for the duration of the 6-wk experiment, whereas multiparous cows decreased at a greater weekly rate. Similarly, yields for ECM and 4\% FCM did not change. Ipharraguerre et al. (2002) showed there was no effect on milk and FCM when SH was included up to $30 \%$ in the diet as a replacement for corn. Decreasing dietary starch from 30.2 to $14.0 \%$ by replacing wheat with SH also had no effect on milk and FCM yields (Aikman et al., 2006). Several studies in which SH replaced ground corn up to maximum of $25 \%$ DM also observed no effect of SH inclusion on milk yield (Bernard and McNeill, 1991), but inclusion of SH beyond 30\% decreased milk yield and ECM (Nakamura and Owen, 1989; Ipharraguerre et al., 2002). Inclusion of SH up to $40 \%$ of the dietary DM to replace corn might have decreased milk production by restricting both amount and source of energy available (Ipharraguerre et al., 2002). This could have been attributed to decreased DMI and to a decreased amount of NSC digested in the rumen and intestine.

Milk component yields, including fat, protein, lactose, and total solids, were also not affected by diet. Interactions of parity $\times$ week $(P<0.05)$ were observed for yields of FCM, fat, protein, lactose, and total solids resulting from differences observed in milk yield. Percentages of fat, protein, lactose, and total solids followed the same pattern, where no significant differences were observed. Milk fat percentage was unaffected when lactating dairy cows were fed diets with $30 \%$ or less SH on DM basis in place of starch (Mansfield and Stern, 1994; Aikman et al., 2006). Mansfield and Stern (1994) suggested that similar molar percentages of total lipogenic VFA (acetate and butyrate) may have resulted in similar milk fat percentage compared with diets with high concentrations of corn. However, milk fat percentage or yield normally increases when SH replaces more than 30\% of corn in high-grain diets (Nakamura and Owen, 1989; Sarwar et al., 1992; Ipharraguerre et al., 2002). No dietary effect on milk protein composition and yield in the present study agrees with previous research by Ipharraguerre et al. (2002). However, Aikman et al. (2006) reported that milk protein concentration decreased linearly as SH replaced wheat starch concentration in lactating dairy cow diets. These authors postulated that the lower milk protein concentration could be attributed to limited mammary protein synthesis because inclusion of $\mathrm{SH}$ may decrease the concentration of specific AA (methionine) and low degradability of SH protein. Milk urea nitrogen was not affected by reducing dietary starch. Feed efficiency, defined as ECM/DMI, tended to increase linearly ( $P$ $<0.07)$ as starch from corn was replaced with nonforage NDF from DDGS and SH (Table 5). The greatest feed efficiency was observed for the diet with the lowest starch concentration. This could possibly be attributable to lower availability of fat and protein from DDGS in the rumen and increased passage to the small intestine, where they are directly utilized by the animal with 
Table 6. Fatty acid composition of milk from cows fed diets with decreasing concentrations of dietary starch

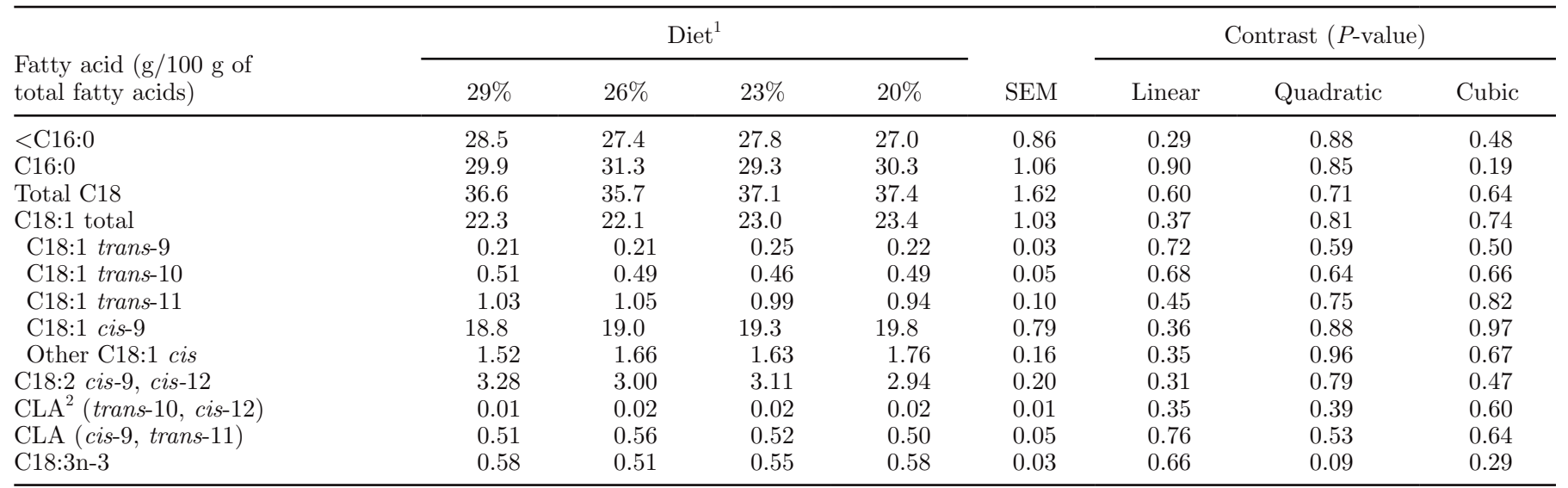

${ }^{1}$ Diets provided decreasing concentrations of starch: $29 \%$ starch with $0 \%$ dried distillers grains with solubles (DDGS); $26 \%$ starch with $7 \%$ DDGS; $23 \%$ starch with $14 \%$ DDGS; and 20\% starch with $21 \%$ DDGS.

${ }^{2} \mathrm{CLA}=$ conjugated linoleic acid.

a greater efficiency (Klopfenstein et al., 2008; Anderson et al., 2009). In contrast to DDGS, fat and protein from corn and soybeans are subjected to greater degradation and fermentation in the rumen, resulting in lower feed efficiency.

Milk fatty acid profiles are shown in Table 6 . Reducing dietary starch concentration by replacing it with nonforage fiber had no effect on any of the fatty acids or fatty acid classes across diets. Even though dietary unsaturated fatty acids increased from 58.0 to $74.2 \%$ and, more specifically, linoleic acid increased from 27.1 to $38.3 \%$ of the total fatty acids as dietary starch decreased across diets (Table 1), there was no effect on milk fatty acid composition (Table 6). No differences in milk fat and milk fatty acid composition across all treatments leads to speculation that all cows maintained normal rumen function during the study and that ruminal biohydrogenation by rumen microorganism was not affected by dietary treatments. Therefore, in this study, adequate physically effective fiber resulted in normal rumen function even though unsaturated fat from DDGS was substantially increased as nonforage fiber replaced starch.

\section{Economic Analysis of the Diets}

Average price for class III milk used for all calculations was $\$ 0.31 / \mathrm{kg}$, and the same value was used when calculating IOFC because there were no differences observed for milk components. Calculated feed costs ( $\$ /$ cow per day) were $4.91,4.53,3.94$, and 3.49 for 29 , 26, 23, and $20 \%$ starch diets, respectively. Calculated IOFC (\$/cow per day) were 7.02, 7.40, 7.98, and 8.44 for $29,26,23$, and $20 \%$ starch diets, respectively. The economic analysis of the present study showed that there was a decrease in feed cost when corn starch was replaced with DDGS and SH. This was attributable to replacing corn, soybean meal, and expellers soybean meal with lower cost, nonforage fiber sources, in combination with greater feed efficiency demonstrated by cows fed lower-starch diets. The economic advantage gained from feeding DDGS and SH by replacing starch was reflected in IOFC. According to IOFC analysis, an economic advantage of $\$ 1.42 /$ cow per day was observed in this study when feeding the $20 \%$ starch diet compared with the $29 \%$ starch diet.

\section{CONCLUSIONS}

Replacing starch from corn with nonforage NDF from DDGS and SH in lactating dairy cow diets did not affect milk production or composition. Dry matter intake decreased as nonforage fiber replaced starch in the diets. There was a tendency to increase feed efficiency as DMI was decreased at higher nonforage fiber concentrations. Moreover, increased feed efficiency and the replacement of higher cost starch and protein feedstuffs with lower cost nonforage fiber and protein feedstuffs decreased diet feed costs. Greater conversion of feed to milk combined with lower cost diets could increase profitability from cows fed diets formulated with greater amounts of nonforage feedstuffs at lower dietary starch concentrations.

\section{ACKNOWLEDGMENTS}

The authors express appreciation to Kevin Gross, Pete Linke, and personnel at the South Dakota State 
University Dairy Teaching and Research Facility for the feeding and care of the animals and to Malek Abdelqader, Jill Anderson, and Kamal Mjoun for assistance in sample collection and analysis. This research was supported in part by funds from the South Dakota Agricultural Experiment Station (Brookings, SD) and USDA-ARS Agreement No. 58-5447-7-322.

\section{REFERENCES}

Abdelqader, M. M., A. R. Hippen, D. J. Schingoethe, K. F. Kalscheur K. Karges, and M. L. Gibson. 2009. Corn germ from ethanol production as an alternative fat source in dairy cow diets. J. Dairy Sci. 92:1023-1037.

Aikman, P. C., D. E. Beever, and D. J. Humphries. 2006. The effect of incremental replacement of wheat with soya hulls in diets for Jersey cows on lactational performance, diet digestibility and feeding behaviour. Livest. Sci. 104:23-32.

Allen, M. S., B. J. Bradford, and K. J. Harvatine. 2005. The cow as a model to study food intake regulation. Annu. Rev. Nutr. $25: 523-547$.

Anderson, J. L., K. F. Kalscheur, A. D. Garcia, D. J. Schingoethe, and A. R. Hippen. 2009. Ensiling characteristics of wet distillers grains mixed with soybean hulls and evaluation of the feeding value for growing Holstein heifers. J. Anim. Sci. 87:2113-2123.

Anderson, J. L., D. J. Schingoethe, K. F. Kalscheur, and A. R. Hippen. 2006. Evaluation of dried and wet distillers grains included at two concentrations in the diets of lactating dairy cows. J. Dairy Sci. 89:3133-3142.

AOAC. 2002. Official Methods of Analysis. 18th ed. Association of Official Analytical Chemists, Gaithersburg, MD.

AOCS. 2004. Rapid determination of oil/fat utilizing high temperature solvent extraction. Official method Am 5-04 oil. Official Methods and Recommended Practices of the AOCS. American Oil Chemists Society, Champaign, IL.

Bernard, J. K., and W. W. McNeill. 1991. Effect of high fiber energy supplements on nutrient digestibility and milk production of lactating dairy cows. J. Dairy Sci. 74:991-995.

Clark, P. W., and L. E. Armentano. 1997. Influence of particle size on the effectiveness of beet pulp fiber. J. Dairy Sci. 80:898-904.

Erwin, E. S., G. J. Marco, and E. Emery. 1961. Volatile fatty acid analysis of blood and rumen fluid by gas chromatography. J. Dairy Sci. 44:1768-1771.

Firkins, J. L. 1997. Effects of feeding nonforage fiber sources on site of fiber digestion. J. Dairy Sci. 80:1426-1437.

Forbes, J. M. 1995. Voluntary Food Intake and Diet Selection in Farm Animals. CAB International, New York, NY.

Harmison, B., M. L. Eastridge, and J. L. Firkins. 1997. Effect of percentage of dietary forage neutral detergent fiber and source of starch on performance of lactating Jersey cows. J. Dairy Sci. 80:905-911.

Ipharraguerre, I. R., and J. H. Clark. 2003. Soyhulls as an alternative feed for lactating dairy cows: A review. J. Dairy Sci. 86:10521073.

Ipharraguerre, I. R., R. R. Ipharraguerre, and J. H. Clark. 2002. Performance of lactating dairy cows fed varying amounts. J. Dairy Sci. 85:2905-2912.

Kalscheur, K. F. 2005. Impact of feeding distillers grains on milk fat, protein, and yield. Proc. Distillers Grains Technology Council, 9th Annual Symposium, Louisville, KY. Distillers Grains Technology Council, Louisville, KY.

Kalscheur, K. F., B. B. Teter, L. S. Piperova, and R. A. Erdman. 1997. Effect of dietary forage concentration and buffer addition on duodenal flow of trans- $\mathrm{C}_{18 \cdot 1}$ fatty acids and milk fat production in dairy cows. J. Dairy Sci. 80:2104-2114.

Kleinschmit, D. H., J. L. Anderson, D. J. Schingoethe, K. F. Kalscheur, and A. R. Hippen. 2007. Ruminal and intestinal degradability of distillers grains plus solubles varies by source. J. Dairy Sci 90:2909-2918.

Kleinschmit, D. H., D. J. Schingoethe, K. F. Kalscheur, and A. R. Hippen. 2006. Evaluation of various sources of corn dried distillers grains plus solubles for lactating dairy cattle. J. Dairy Sci. 89:4784-4794.

Klopfenstein, T. J., G. E. Erickson, and V. R. Bremer. 2008. Boardinvited review: Use of distillers by-products in the beef cattle feeding industry. J. Anim. Sci. 86:1223-1231.

Kononoff, P. J., and A. J. Heinrichs. 2003. The effect of reducing alfalfa haylage particle size on cows in early lactation. J. Dairy Sci. 86:1445-1457

Kononoff, P. J., A. J. Heinrichs, and D. R. Buckmaster. 2003 Modification of the Penn State forage and total mixed ration particle separator and the effects of moisture content on its measurements. J. Dairy Sci. 86:1858-1863.

Lammers, B. P., D. R. Buckmaster, and A. J. Heinrichs. 1996. A simple method for the analysis of particle sizes of forage and total mixed rations. J. Dairy Sci. 79:922-928.

Leiva, E., M. B. Hall, and H. H. Van Horn. 2000. Performance of dairy cattle fed citrus pulp or corn products as sources of neutral detergent-soluble carbohydrates. J. Dairy Sci. 83:2866-2875.

Littell, R. C., G. A. Milliken, W. W. Stoup, R. D. Wolfinger, and O. Schabenberger. 2006. SAS for Mixed Models. 2nd ed. SAS Institute, Cary, NC.

Mansfield, H. R., and M. D. Stern. 1994. Effects of soybean hulls and lignosulfonate-treated soybean meal on ruminal fermentation in lactating dairy cows. J. Dairy Sci. 77:1070-1083.

Mertens, D. R. 1994. Regulation of feed intake. Pages 450-493 in Forage Quality, Evaluation, and Utilization. G. C. Fahey, ed. American Society of Agronomy Inc., Madison, WI.

Mould, F. L., E. R. Ørskov, and S. O. Mann. 1983. Associative effects of mixed feeds. I. Effects of type and level of supplementation and the influence of the rumen fluid $\mathrm{pH}$ on cellolysis in vivo and dry matter digestion of various roughages. Anim. Feed Sci. Technol. 10:15-30.

Nakamura, T., and F. G. Owen. 1989. High amounts of soyhulls for pelleted concentrate diets. J. Dairy Sci. 72:988-994.

NRC. 2001. Nutrient Requirements of Dairy Cattle. 7th rev. ed. Natl. Acad. Sci., Washington, DC.

Orth, R. 1992. Sample day and lactation report. DHIA 200 Fact Sheet A-2. Mid-States DRPC, Ames, IA.

Robertson, J. B., and P. J. Van Soest. 1981. The detergent system of analysis and its application to human foods. Pages 123-158 in The Analysis of Dietary Fiber in Food. W. P. T. James and O. Theander, ed. Marcel Dekker Inc., New York, NY.

Sarwar, M., J. L. Firkins, and M. L. Eastridge. 1992. Effects of varying forage or concentrate carbohydrates on nutrient digestibilities and milk production by dairy cows. J. Dairy Sci. 75:1533-1542.

SAS Institute. 2001. SAS User's Guide: Statistics. Version 9.01. SAS Institute Inc., Cary, NC.

Sasikala-Appukuttan, A. K., D. J. Schingoethe, A. R. Hippen, K. F. Kalscheur, K. Karges, and M. L. Gibson. 2008. The feeding value of corn distillers solubles for lactating dairy cows. J. Dairy Sci. 91:279-287.

Schingoethe, D. J., K. F. Kalscheur, A. R. Hippen, and A. D. Garcia. 2009. Invited review: The use of distillers products in dairy cattle diets. J. Dairy Sci. 92:5802-5813.

Shreve, B., N. Thiex, and M. Wolf. 2006. NFTA method 2.1.4-Dry matter by oven drying for 3 hours at $105^{\circ} \mathrm{C}$. NFTA Reference Methods. National Forage Testing Association, Omaha, NE. http:// www.foragetesting.org/files/NFTAReferenceMethodDM-09-18-06. pdf Accessed February 6, 2009.

Strobel, H. J., and J. B. Russell. 1986. Effect of pH and energy spilling on bacterial protein synthesis by carbohydrate-limited cultures of mixed rumen bacteria. J. Dairy Sci. 69:2941-2947.

Trinder, P. 1969. Determination of glucose in blood using glucose oxidase with an alternative oxygen acceptor. Ann. Clin. Biochem. 6:24-27.

Undersander, D., D. R. Mertens, and N. Thiex. 1993. Forage Analysis Procedures. National Forage Testing Association, Omaha, NE. 
USDA. 2009. Feed Prices: 12 January 2009. Economic Research Service, United States Department of Agriculture, Washington, DC. http://www.ers.usda.gov/Data/feedgrains/tables.aspx Accessed Jan. 31, 2009.

Van Soest, P. J., J. B. Robertson, and B. A. Lewis. 1991. Methods for dietary fiber, neutral detergent fiber, and non-starch polysaccharides in relation to animal nutrition. J. Dairy Sci. 74:3583-3597.

Voelker, J. A., and M. S. Allen. 2003. Pelleted beet pulp substituted for high-moisture corn: 1. Effects on feed intake, chewing behavior, and milk production of lactating dairy cows. J. Dairy Sci. $86: 3542-3552$.

Wildman, E. E., G. M. Jones, P. E. Wagner, R. L. Boman, H. F. Troutt Jr., and T. N. Lesch. 1982. A dairy cow body condition scoring system and its relationship to standard production characteristics. J. Dairy Sci. 65:495-501.

Williamson, D. H., J. Mellanby, and H. A. Krebs. 1962. Enzymatic determination of $\mathrm{D}(-) \beta$-hydroxybutyrate and acetoacetic acid in blood. Biochem. J. 82:90-96. 